\title{
The role of meteorological and climatic conditions in the occurrence of damaging hydro-geologic events in Southern Italy
}

\author{
O. Petrucci ${ }^{1}$ and M. Polemio ${ }^{2}$ \\ ${ }^{1}$ CNR-IRPI, Dept. of Cosenza, Italy, \\ ${ }^{2}$ CNR-IRPI, Dept. of Bari, Via Amendola 122/i, 70124 Bari, Italy
}

Received: 28 October 2008 - Revised: 11 December 2008 - Accepted: 11 December 2008 - Published: 12 February 2009

\begin{abstract}
Damaging Hydro-geologic Events (DHEs), defined as landslides and floods caused by heavy or prolonged rainfall, represent an important source of economic damages. We propose an approach to classify DHEs, considering 1) meteorological antecedent conditions, 2) the season during which the event occurs, 3) the return period of maximum daily rainfall triggering the event, 4) geographic sectors hit, 5) types of triggered damaging phenomena; and 6) induced damage.
\end{abstract}

We applied this approach to a case study of time series of DHEs that occurred over 85 years in Calabria (southern Italy). We analysed 13 DHEs that, between 1921 and 2005, triggered landslides, floods and secondary floods, causing severe damage and tens of causalities all over the Calabria region. During the analysed events, $64 \%$ of Calabria's municipalities suffered many types of damage. The most relevant rain phenomena and the largest damages were caused by the persistent effects of perturbations on Calabria, which were preceded by the appearance of low-pressure fields in two different areas located westwards.

We sorted the events into three types based on geographic damage distribution and types of triggered phenomena and induced damage. The first two types are characterised by similar severity levels, while the third shows the highest severity, in terms of both damage and victims. Independent of the type of event, the S-SE and E sectors of the region are the most frequently affected by DHEs. As regards human life, floods are the most dangerous type of phenomenon, causing the highest number of fatalities.

Our analysis indicates a decreasing frequency of DHEs during the study period, and an absence of the most severe type for more than 50 years. The number of victims is also decreasing over time.

Correspondence to: $\mathrm{M}$. Polemio

(m.polemio@ba.irpi.cnr.it)

\section{Introduction}

Prolonged and/or intense rainfall can trigger damaging phenomena, such as landslides, floods and secondary floods (stagnancy of rain on low permeability surfaces), causing damage and fatalities. As a whole, these periods of bad weather and triggered phenomena can be defined as Damaging Hydro-geological Events (DHEs) (Petrucci and Polemio, 2003; Petrucci et al., 2009).

The social and economic costs of DHEs are not well documented because no agency is formally charged to gather data concerning them (I.F.R.C., 2001). In particular, damage to some elements, such as roads, are often merged with maintenance costs and therefore not labelled as damage induced by DHEs (Highland, 2003).

Historical research can supply useful data concerning past DHEs. Books, newspapers and official refund requests can provide information concerning both triggered phenomena and induced damage. By assuming that the behaviour of processes is uniform, an analysis of the recent past enables forecasting of similar events in the future (Remondo et al., 2008).

The attention paid to DHEs has increased during recent years because of their costly effects and the need to cope with them (Barnikel and Becht, 2003; Diodato, 2004; Giannecchini, 2005; Luino, 2005; Petrucci and Pasqua, 2008).

The first goal is to identify the areas most frequently damaged. In fact, if no defensive measures are undertaken, these areas could be damaged again in the future. This information can drive planning of hazard mitigation measures, ranking them according to the magnitude of expected damage. Characterising DHEs that have occurred in a study area, in terms of both effects and triggering meteorological and rainfall conditions, can also outline areas most likely to be hit, the potential resulting damage and warning criteria useful for civil protection purposes (Petrucci and Polemio, 2002). In addition, by comparing the exceptionality levels of triggering rainfall and induced damage, we can outline susceptibility

Published by Copernicus Publications on behalf of the European Geosciences Union. 
zones of areas likely to be damaged during DHEs (Petrucci and Pasqua, 2008). All of this information can be used in both urban planning and emergency plan preparation, aiming to forecast and reduce damage induced by DHEs.

\section{Method and type of data}

Our proposed method aims to characterise both meteorological conditions and triggering rainfall for the different types of DHEs that affect a study area, in order to supply data to prevent and mitigate damage.

Geographic and political boundaries can be used to divide the study area into subsets that match with administrative provinces. These can be further divided into smaller subsets fitting with municipalities. For each of these subsets, we must collect and cross-check long time series of data concerning:

a) hydrogeological phenomena and their induced damage;

b) daily rainfall; and

c) meteorological synoptic conditions.

a) Hydrogeological phenomena and their induced damage can be investigated by means of historical surveys. Several types of documents provide historical data on past landslides and floods (Ibsen and Brunsden, 1996; Llasat et al., 2006; Lastoria et al., 2006). This information does not always directly describe a particular phenomenon, but may rather simply expose its effects or impacts (Benito et al., 2004). In addition, not all information is of optimum reliability and a critical analysis of sources is required (Glaser, 1996; Devoli et al., 2007). However, although historical data are limited (Petrucci and Pasqua, 2008), they are sometimes the only way to outline the historical series of damaging phenomena that occurred in a study area.

Collected data, classified by municipality, must be sorted chronologically in order to identify DHEs. These are periods (from days to up to a month, depending on the local climatic setting) during which damaging landslides and floods occurred in several sectors of the study area. When a consistent number of DHEs has been identified, a sub-set of the most significant cases can be selected. This choice must be done to select DHEs as different as possible, aiming to analyse the complete range of event types affecting the study area.

b) The return period of daily rainfall $(T)$ observed during each DHE is used to describe the exceptionality of the triggering rainfall. For each gauge, the time series of annual maxima of daily rainfall should be evaluated and the probability distribution function of these peak values assessed. One reliable choice is the GEV (Generalized Extreme Value) probability distribution function (Jenkinson, 1955), which is defined by three parameters that can be assessed using the PWM (Probability-Weighted Moments) method (Hosking,
1986). This method supplies consistent results, particularly if outliers are not observed (Polemio and Sdao, 1999). If outliers are observed, the regionalisation approach to parameter definition is preferred. In this case, a four-parameter probability distribution function, like the TCEV (Two Component Extreme Value) (Rossi and Versace, 1982), ensures higher reliability in the assessment of $T$.

Thus, for each gauge working during a DHE, the return period $(T)$ of the maximum daily rainfall observed during the DHE must be assessed. This value can be assumed to be representative of the exceptionality of the rainfall that triggered the event.

For each event, according to the $T$ maxima, the gauges can be sorted into 4 classes of increasing exceptionality (class 1: $T \leq 2$ years; class 2: $2<T \leq 10$ years; class 3: $10<$ $T \leq 20$ years; class 4: $T>20$ years), and the results of this classification can be mapped so as to visualise the spatial distribution of exceptional rainfall.

c) The meteorological synoptic conditions of a period in which a DHE occurred can be assessed by analysing isotherms, the geo-potential, and isobar synoptic maps, daily weather reports and forecasts. For some decades, meteorological remote sensing data are also available. For more than 30 years, these data have been used to provide reliable assessments of the evolution of local heavy storms over large areas (Yang et al., 2007). In many cases, early warnings have helped prevent casualties and damages due to heavy rainfall, thunderstorms and hurricanes (Houze et al., 1990).

This type of approach suffers from some restrictions. Difficulties arise in the synergetic use of remote sensing and in situ data, which are characterised by different spatial and time resolutions (Buchroithner, 2002). However, the chief problem is the impossibility of completing the meteorological analysis backwards. This limitation very often blocks the use of the longest available time series concerning DHEs, as could be necessary in the case of large inhomogeneous areas.

The availability of primary data, such as pressure, temperature, and humidity content of the atmosphere, and wind data is the starting point for meteorological analysis (Saucier, 2003). These types of data can be found in meteorological synoptic maps of isotherms, geopotential, and/or bar lines, daily weather reports and forecasts, which are the simplest sources for meteorological analysis. These sources generally include synoptic rainfall data and, in some cases, also contain descriptions of the observed extreme meteorological events.

During the latest decades, these data have been published worldwide on a daily basis by local, national or international meteorological forecasting services (some maps even provide data for four times a day), with some local or national differences (Saucier, 2003). Recently, free web and ftp servers have begun to supply more than one of these sources of data and maps per day (http://www.ncep.noaa.gov is a useful source).

The meteorological analysis is based on a traditional approach (Barry et al., 2003; Saucier, 2003) called expert-eye- 
scanning (Yang et al., 2007). The analysis of the whole data aims to define the typical antecedent meteorological conditions that produce heavy rainfalls that lead to DHEs in the study area. The main purpose is to recognise, for each DHE, the atmospheric pattern that created the perturbations and the paths of these perturbations. The repetitiveness of antecedent meteorological conditions is analysed so as to use it to improve damage forecasting and mitigation.

\section{Characterisation of DHEs affecting the Calabria region}

Italian territory, due to its climatic, geomorphological and anthropogenic framework, is frequently hit by DHEs. Landslides and floods triggered by intense and/or prolonged rainfall induce severe damage and fatalities in almost all of its regions (Guzzetti, 2000). Calabria, the southernmost region, is frequently and strongly hit by these kinds of events.

Within a research program started several years ago, a method for characterising DHEs has been structured and tested on a study area $\left(686 \mathrm{~km}^{2}\right)$ located in SE Calabria (Petrucci and Polemio, 2002, 2003). The analysis has identified some major types of DHEs that can be distinguished according to the following features: 1) types of damaging phenomena triggered; 2) geographic sectors hit; 3) season in which the event occurred; 4) antecedent meteorological conditions; 5) return period of maximum daily rainfall triggering the event; and 7) induced damage.

In the present work, we extend the above approach to a regional study area, so-called Calabria $\left(15230 \mathrm{~km}^{2}\right)$, which includes the above-mentioned study area. In addition, in order to search for a characterisation of DHEs that can be used in forecasting and mitigation of damage, we tried to typify meteorological conditions preceding the different types of events observed.

\subsection{Features of the Calabria region}

\subsubsection{Geological features}

Calabria is a peninsular region characterised by elevations up to $2000 \mathrm{~m}$ a.s.l. From a geological point of view (Fig. 1), it is made up of allochthonous crystalline rocks (from the Palaeozoic to the Jurassic), stacked during the middle Miocene (Tortorici, 1982) over carbonate units (Ogniben, 1973). Neogene flysch fills tectonic depressions. Starting from the Quaternary, the region has been subjected to still-active uplift. Tectonic stresses and climatic conditions deteriorate the characteristics of rocks, predisposing slopes to instability phenomena. In addition, the river network mainly consists of ephemeral streams that, after short and intense rainfall, undergo severe flash floods.

In this framework, the latest DHEs (D'Andrea and Petrucci, 2003; Sorriso et al., 2004) represent only a small

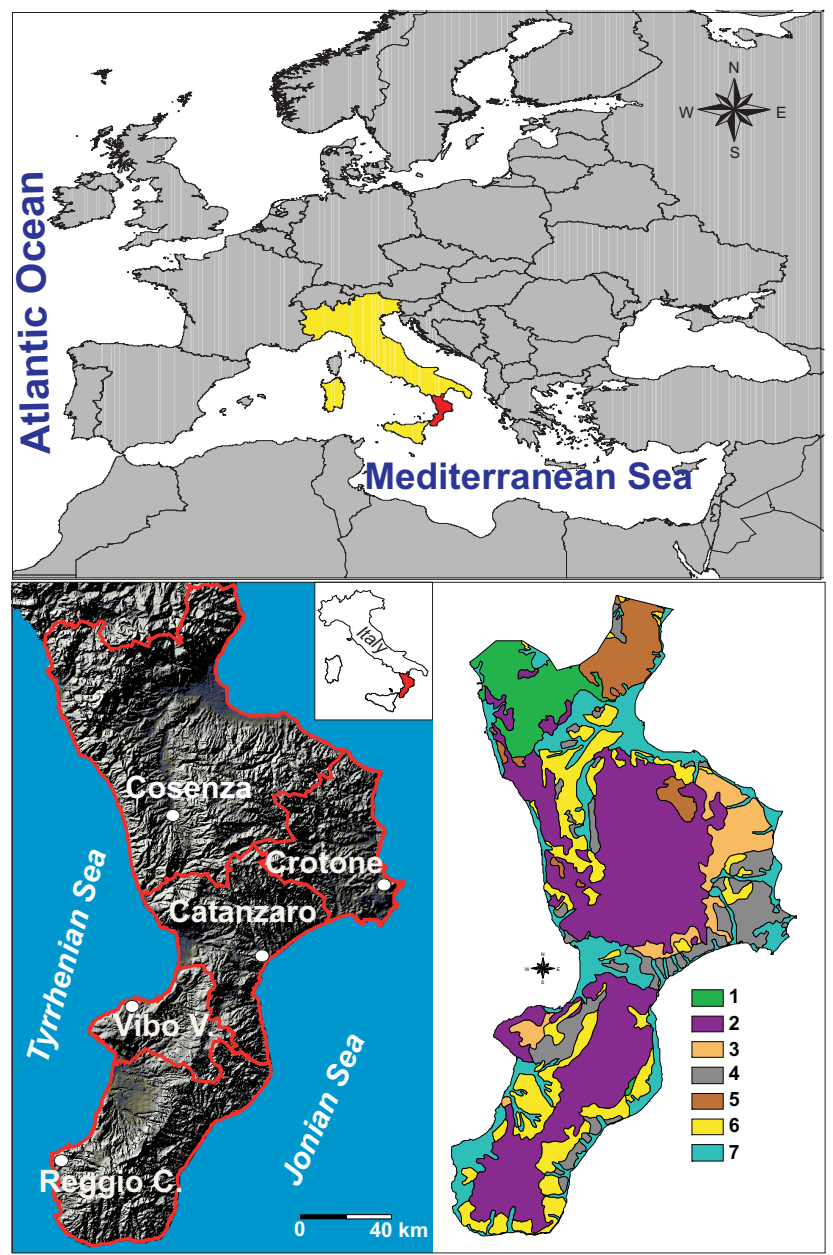

Fig. 1. Top: Mediterranean basin: Italy in yellow and Calabria in red. Bottom left: shaded relief map of Calabria and province boundaries (Abbreviations: Reggio Calabria=Reggio C.; Vibo Valentia=Vibo V.). Bottom right: simplified geological sketch of the region. Keys: 1) limestone and dolostone; 2) metamorphic and igneous rocks; 3) clays, marls and evaporitic rocks; 4) sandstones, marly clays and limestone marls; 5) flysch and clayey formations; 6) conglomerates, sands and sandstones; and 7) alluvial deposits.

fragment of a very long sequence of similar events that affected almost the entire region, resulting in victims and severe damage (Petrucci et al., 1996; Petrucci and Versace, 2005, 2007).

\subsubsection{Meteorological framework}

Calabria is located in the central part of the Mediterranean Sea. Here, the Azores high pressure strengthens during the summer, spreading northwards and often dominating North Africa (Barry and Chorley, 2003; Saucier, 2003). This creates the typical summer Mediterranean conditions, characterised by clear, hot and still weather. Any rainfall is due 
to convective activity in the moist air over the sea. In autumn, the high-pressure decreases: generally, its influence on the Mediterranean basin ends quite abruptly in October. When this happens, due to the jet stream of the polar-front and the increasing strength of the Siberian high-pressure area, westerlies can move from the Atlantic Ocean to the Mediterranean Sea, causing rainfall sometimes enhanced by the warm Mediterranean Sea. During the autumn and winter, the pattern of atmospheric circulation is almost stable.

As a result, during these seasons, rainfall can also be due to depressions originating in the Mediterranean basin itself (Naden et al., 1993). In general, these rains are due to cold northerly air that arrives in the northern Mediterranean flowing between the Alps and the Pyrenees. When the thermal gradient between the air mass and the sea is adequate, this second type of rain can arise.

Due to the increasing influence of the Azores high pressure, and the decreasing role of the Siberian ones, spring is characterised by unstable conditions.

\subsubsection{Climatic features}

Calabria has a mild Mediterranean climate, with dry summers (monthly minimum rainfall in July or August) and wet winters (widespread monthly maximum rainfall in December or January). The mean regional annual rainfall $(1151 \mathrm{~mm})$ is higher than the national value $(970 \mathrm{~mm})$. Due to the movement of meteorological perturbations, predominantly from west to east, the rainiest area is the west side of the region. Nevertheless, the east sector is often hit by very intense storms (Versace et al., 1989). Because of the peninsular character of Calabria, increasing the heat/moist exchange with the sea, and the enhancement due to the relief, intense daily rainfall can occur in autumn-winter. During these seasons, daily rainfall up to $30-35 \%$ of mean annual rainfall triggers the most severe DHEs, especially in the eastern part of the region (Petrucci and Polemio, 2002).

\subsection{Description of selected DHEs}

Data concerning DHEs that occurred in Calabria can be gathered from two main sources:

a) ASICal (Aree Storicamente Inondate in Calabria) is a database of landslides and floods that occurred in Calabria during the past centuries (http://www.camilab.unical.it); it was produced by a joint research project of the CNR-IRPI of Cosenza and the Department of Soil Defence of Calabria University (Petrucci and Versace, 2004). At present, it contains about 6000 records selected from newspapers, archives and technical articles.

b) HistArc (Historical Archive) is an archive available at the CNR-IRPI of Cosenza that contains more than 10000 paper documents from a variety of Calabria's agencies (such as the regional Department of Public Works). Most of the data concern damage refunding for DHEs that occurred between 1890 and 1990.

The choice of the events to be studied was restricted by rainfall data, which are available from 1921. Taking into account this restriction, we selected 13 DHEs for which all of the required data were available. For each DHE, data concerning triggered phenomena and induced damage were sorted chronologically and by municipality. The data allowed us to distinguish between three main types of phenomena: landslides, floods and secondary floods.

The main features of the selected DHEs are shown in Table 1, in which the events have been listed from earliest to latest. The columns L (Landslides), F (Floods) and Sf (Secondary floods) summarise the incidence of each type of phenomenon, expressed as a percentage of the total number that occurred in the analysed DHE. A $\left(\mathrm{km}^{2}\right)$ is the area obtained by summing the areas of all the municipalities in which, during the event, some phenomenon occurred. A is greater than the area truly affected, but this simplification is necessary to by-pass the impossibility of delimiting areas really hit that characterises most cases. Moreover, the municipal scale is the basic level to compare rainfall, damaging phenomena and damages.

IDA, the Index of Damaged Area, expresses the percentage of regional area affected by the event; it is calculated by dividing A by the area of the whole region. The number of victims is also reported in Table 1, but this information could be underestimated. In fact, in some cases, we found documents or newspaper articles mentioning missing people. Since no other data were found about these people, we assumed that they were rescued.

The Damage Index of the Event (DIE) expresses, in a semi-quantitative way, the damage induced by the event. To assess the DIE, we slightly modified an approach applied in previous works (Petrucci and Polemio, 2003). Damage is assumed to be the product of the value of the damaged element and level of loss that the element suffered during the event. The value of the damaged element ranges from 1 to 10 , on an arbitrary scale in which the elements are sorted into nine types (Road network; Railway network; Housing areas; Public buildings; Services networks; Productive activities; Tourist and sport resorts; Hydraulic works; People). The levels of loss have been set as L1=high 1), L2=medium (0.5) and L3=low (0.25). In order to give the highest weight to human life, the value of people has been set as 100 and the levels of loss have been set as $\mathrm{L} 1=$ more than 10 victims; $\mathrm{L} 2=$ from 5 to 10 victims; L3=less than 5 victims. For each DHE, we used this approach to process the total damage caused. If, during the analysed DHE, a certain element (for example the road network) was damaged in more than one case/place, we assumed the case in which the level of damage was the highest to be representative. The sum of all the products of damaged elements by the respective levels of loss is the DIE value.

Analysing the features described in Table 1, the geographic distribution of damaged area and the spatial- 
Table 1. Main features of the analysed DHEs. $N$ : identification number of the event; Year: year of occurrence; From: day the first damage was noticed; To: day the last damage was noticed; D (days): duration of the event; L (\%), F (\%) and Sf (\%): number of Landslides, Floods and Secondary floods expressed as percentage of the total number of phenomena that occurred during the analysed DHE; A $\left(\mathrm{km}^{2}\right)$ : sum of the area of damaged municipalities; IDA (\%): Index of Damaged Area (see Sect. 2); Victims: number of fatalities caused by each event; DIE: Damage Index of the Event (see Sect. 3.2).

\begin{tabular}{|c|c|c|c|c|c|c|c|c|c|c|c|c|}
\hline & N. & Year & From & To & $\mathrm{D}$ (days) & $\mathrm{L}(\%)$ & $\mathrm{F}(\%)$ & Sf (\%) & $\mathrm{A}\left(\mathrm{km}^{2}\right)$ & IDA & Victims & DIE \\
\hline \multirow{5}{*}{ A } & 3 & 1927 & $29 \mathrm{Nov}$ & $9 \mathrm{Dec}$ & 11 & 38 & 41 & 22 & 1103 & 7.24 & 6 & 105.5 \\
\hline & 4 & 1930 & $20 \mathrm{Feb}$ & $23 \mathrm{Feb}$ & 4 & 10 & 78 & 12 & 1504 & 9.88 & 1 & 65.5 \\
\hline & 10 & 1971 & $1 \mathrm{Oct}$ & $3 \mathrm{Oct}$ & 3 & 37 & 47 & 17 & 1772 & 11.63 & 2 & 63 \\
\hline & 11 & $1972-1973$ & $15 \mathrm{Dec}$ & 3 Jan & 20 & 51 & 47 & 2 & 3801 & 24.95 & 4 & 105.5 \\
\hline & 13 & 2000 & 9 Sep & $15 \mathrm{Sep}$ & 7 & 38 & 18 & 44 & 3795 & 24.91 & 12 & 173 \\
\hline \multirow{5}{*}{ B } & 1 & 1921 & 25 Oct & 29 Oct & 5 & 57 & 39 & 4 & 923 & 6.06 & 12 & 136.5 \\
\hline & 2 & 1925 & $22 \mathrm{Nov}$ & $30 \mathrm{Nov}$ & 9 & 38 & 27 & 35 & 748 & 4.91 & 15 & 137 \\
\hline & 6 & 1933 & $30 \mathrm{Nov}$ & $8 \mathrm{Dec}$ & 9 & 55 & 26 & 19 & 2807 & 18.43 & 8 & 99.5 \\
\hline & 9 & 1959 & $20 \mathrm{Nov}$ & $26 \mathrm{Nov}$ & 7 & 53 & 34 & 13 & 2718 & 17.84 & 10 & 129 \\
\hline & 12 & 1990 & $13 \mathrm{Dec}$ & $28 \mathrm{Dec}$ & 16 & 67 & 13 & 21 & 1848 & 12.13 & 0 & 48 \\
\hline \multirow{3}{*}{$\mathrm{C}$} & 5 & 1932 & $9 \mathrm{Nov}$ & $16 \mathrm{Nov}$ & 8 & 37 & 58 & 5 & 914 & 6.00 & 34 & 142 \\
\hline & 7 & 1951 & 7 Oct & $24 \mathrm{Oct}$ & 18 & 36 & 64 & 0 & 1964 & 12.89 & 67 & 158 \\
\hline & 8 & 1953 & $21 \mathrm{Oct}$ & 13 Nov & 24 & 28 & 64 & 8 & 4242 & 27.84 & 25 & 189 \\
\hline
\end{tabular}

temporal distribution of damage data, we clustered the 13 analysed DHEs into three groups described below. The triggered phenomena and the municipalities hit by each DHE have been schematised on a regional scale (Figs. 2, 3 and 4).

\subsubsection{Events of Type A}

Type A are events during which damage starts to be perceived in the northernmost sectors of the region; then, after a few days, the S-SE sectors also become involved (Fig. 2). This group contains 5 events (Nos. 3, 4, 10, 11, and 13). These events occur over the largest range of dates, from September (No. 13) to February (No. 4). Analysing their duration, it seems that the longer events occur in the middle of this period, between December and January (Nos. 3 and 11). On the other hand, the DHEs that take place at the beginning and end of the period of occurrence are the shortest of the entire dataset (No. 4, lasting for 4 days and No. 10 lasting only 3 days).

Concerning triggered phenomena, floods prevail in three cases (Nos. 3, 4, 10), and floods and landslides show almost the same percentage in one case (No. 11). From this point of view, the DHE No. 13 is different from all the others, because the most abundant phenomena are secondary floods. However, the few flash floods triggered during this event occurred in highly vulnerable places, for example a campsite where 12 people died. This high number of secondary floods is probably tied to very intense hourly rainfall, although this cannot be proven because of the lack of rain gauges surveying hourly rainfall intensity.
The affected area, according to IDA, is as mean value $16 \%$. The mean Damage Index of the Event is 102, but it reaches 173 for event No. 13. The DHEs falling into this group are characterised by a number of victims ranging from 1 and 12 .

\subsubsection{Events of Type B}

The 5 events of this group (Nos. 1, 2, 6, 9, and 12) do not show a specific spatial or temporal pattern of damage (Fig. 3). In practice, all of the involved regional sectors seem to have been hit almost simultaneously and repetitively during periods lasting from 5 to 16 days. These events develop between the end of October and the end of December, and mainly trigger landslides.

The average value of the IDA is $10 \%$, but the low values of IDA for events 1 and 2 have probably been underestimated because of the scarcity of data that characterise these two old events. The average of DIE (91) is lower than for the other two types of events, and this group includes the only DHE that did not cause fatalities (No. 12). In the remaining cases, the number of victims remains under 15 .

\subsubsection{Events of Type C}

This group contains three DHEs that hit the east side of the region, mainly the SE sector (Fig. 4). These events occurred between October and November, and their duration spans 8 to 24 days. Floods are the most numerous triggered phenomena. The mean value of the IDA is $16 \%$, but the IDA of the most recent (and well-documented) DHEs (Nos. 7 and 8) probably best represents the size of the hit area. This group encompasses the most severe events: the mean value of DIE 
Table 2. Meteorological conditions for the analysed DHEs. N) DHE number, Y) year of occurrence.

\begin{tabular}{|c|c|c|c|c|}
\hline $\mathrm{N}$ & $\mathrm{Y}$ & Day/Month & Barometric minimum & Rainfall on Calabria \\
\hline 1. & 1921 & $\begin{array}{l}23-24 / 10 \\
25-26 / 10 \\
27 / 10 \\
28 / 10 \\
29 / 10\end{array}$ & $\begin{array}{l}\text { North Mediterranean and Tyrrhenian Seas } \\
\text { From Sardinia, Sicily to Tunisia } \\
\text { Central Mediterranean Sea and North Africa } \\
\text { Sicily-North Africa } \\
\text { Aegean Sea }\end{array}$ & $\begin{array}{l}\text { Null } \\
\text { Very high } \\
\text { High } \\
\text { Normal } \\
\text { Low }\end{array}$ \\
\hline 2. & 1925 & $\begin{array}{l}12-14 / 11 \\
15-21 / 11 \\
22 / 11 \\
23 / 11 \\
24-28 / 11 \\
29-30 / 11\end{array}$ & $\begin{array}{l}\text { Sardinia and Algeria } \\
\text { Confuse situation } \\
\text { South France and Spain to Morocco } \\
\text { Tyrrhenian Sea to Calabria and North Africa } \\
\text { Confuse situation } \\
\text { Dissolving eastward }\end{array}$ & $\begin{array}{l}\text { Low, locally normal to high } \\
\text { Normal, locally high } \\
\text { Normal, locally high } \\
\text { High to very high } \\
\text { High } \\
\text { Normal }\end{array}$ \\
\hline 3. & 1927 & $\begin{array}{l}20-23 / 11 \\
24-28 / 11 \\
27-30 / 11 \\
1 / 12 \\
2 / 12 \\
3-4 / 12 \\
5-9 / 12\end{array}$ & $\begin{array}{l}\text { Southern France coast } \\
\text { Sardinia to Sicily } \\
\text { Mediterranean Sea } \\
\text { South Mediterranean Sea } \\
\text { Sardinia to Tunisia } \\
\text { Confuse situation } \\
\text { Spain to Sicily }\end{array}$ & $\begin{array}{l}\text { Null, locally normal } \\
\text { Normal } \\
\text { High to very High } \\
\text { High } \\
\text { Normal } \\
\text { Low or null } \\
\text { High ot very high }\end{array}$ \\
\hline 4. & 1930 & $\begin{array}{l}7-9 / 2 \\
10-16 / 2 \\
17-19 / 2 \\
20-21 / 2 \\
22 / 2\end{array}$ & $\begin{array}{l}\text { Mediterranean Sea-Tunisia } \\
\text { Spain to Tunisia } \\
\text { Mediterranean-Adriatic Sea } \\
\text { South Sicily } \\
\text { Dissolving eastward }\end{array}$ & $\begin{array}{l}\text { Normal } \\
\text { Normal to null } \\
\quad \text { Normal } \\
\text { Normal to high } \\
\quad \text { Normal }\end{array}$ \\
\hline 5. & 1932 & $\begin{array}{l}7 / 11 \\
8 / 11 \\
9-12 / 11 \\
13 / 11 \\
14 / 11 \\
15 / 11 \\
16 / 11\end{array}$ & $\begin{array}{l}\text { Spain } \\
\text { Portugal and Northern France } \\
\text { Spain to Northern Africa and Sardinia to Sicily } \\
\text { Calabria } \\
\text { Moving south-eastward } \\
\text { South Sicily to North Africa } \\
\text { Dissolving }\end{array}$ & $\begin{array}{l}\text { Null } \\
\text { Null } \\
\text { High } \\
\text { Very high } \\
\text { Very high } \\
\text { Normal } \\
\text { Low }\end{array}$ \\
\hline 6. & 1933 & $\begin{array}{l}20-22 / 11 \\
23-24 / 11 \\
25-29 / 11 \\
30-1 / 12 \\
2-3 / 12 \\
4-6 / 12 \\
7-9 / 12 \\
10-17 / 12\end{array}$ & $\begin{array}{l}\text { North Africa } \\
\text { Southern Italy to Norway } \\
\text { Dissolving } \\
\text { North Africa and France-North Atlantic Sea } \\
\text { Sicily-Calabria } \\
\text { Dissolving } \\
\text { North Africa and Atlantic Sea } \\
\text { Tyrrhenian Sea to Calabria }\end{array}$ & $\begin{array}{c}\text { Normal } \\
\text { Low } \\
\text { Normal (wide-continuous) } \\
\text { Normal to very high } \\
\text { Very high to high } \\
\text { Normal (wide-continuous) } \\
\text { Normal to null } \\
\text { High to very high }\end{array}$ \\
\hline 7. & 1951 & $\begin{array}{l}27-4 / 10 \\
5-10 / 10 \\
11-14 / 10 \\
15-20 / 10 \\
21-22 / 10 \\
23-24 / 10\end{array}$ & $\begin{array}{l}\text { From Spain to North Africa and from Tyrrhenian Sea, to South Italy } \\
\text { South Tyrrhenian Sea, Calabria, North Africa } \\
\text { Dissolving } \\
\text { From Spain to North Africa and from Tyrrhenian Sea, to South Italy } \\
\text { Dissolving } \\
\text { Tyrrhenian Sea and North Africa }\end{array}$ & $\begin{array}{l}\text { Null or locally normal } \\
\text { High } \\
\text { Low } \\
\text { Very high } \\
\text { Null } \\
\text { Normal }\end{array}$ \\
\hline 8. & 1953 & $\begin{array}{l}6-14 / 10 \\
15-17 / 10 \\
18-20 / 10 \\
21-28 / 10 \\
29-30 / 10 \\
31 / 10 \\
1-5 / 11 \\
6 / 11 \\
7-11 / 11 \\
12-13 / 11\end{array}$ & $\begin{array}{l}\text { Mediterranean Sea } \\
\text { Confuse situation } \\
\text { Confuse situation } \\
\text { From Atlantic Sea to North Europe and North Africa to Tyrrhenian Sea } \\
\text { Dissolving } \\
\text { Confuse situation } \\
\text { From Atlantic Sea to North Europe and North Africa to Tyrrhenian Sea } \\
\text { Moving eastward } \\
\text { West Mediterranean Sea } \\
\text { Dissolving }\end{array}$ & $\begin{array}{l}\text { Low } \\
\text { Null } \\
\text { Normal } \\
\text { Very high } \\
\text { Null } \\
\text { Normal } \\
\text { High } \\
\text { Null } \\
\text { High to normal } \\
\text { Null }\end{array}$ \\
\hline 9. & 1959 & $\begin{array}{l}13-14 / 11 \\
15-20 / 11 \\
21-22 / 11 \\
23-26 / 11\end{array}$ & $\begin{array}{l}\text { Spain and Tunisia } \\
\text { Dissolving } \\
\text { West Mediterranean Sea and Algeria } \\
\text { Tyrrhenian Sea to Calabria }\end{array}$ & $\begin{array}{c}\text { Very High } \\
\text { Normal } \\
\text { Null, locally normal } \\
\text { Very high }\end{array}$ \\
\hline
\end{tabular}


Table 2. Continued.

\begin{tabular}{|c|c|c|c|c|}
\hline $\mathrm{N}$ & $\mathrm{Y}$ & Day/ Month & Barometric minimum & Rainfall on Calabria \\
\hline \multirow[t]{4}{*}{10.} & 1971 & $27 / 9$ & Spain and Tunisia-Sicily & Normal \\
\hline & & $26-28 / 9$ & Spain and Tunisia-Sicily & Very High \\
\hline & & $29-2 / 10$ & North Africa and Italy & very high to high \\
\hline & & $3 / 11$ & Southern Italy moving southward & Normal \\
\hline \multirow[t]{6}{*}{11.} & $1972-1973$ & $20-21 / 12$ & Tunisia-central Mediterranean Sea & Null to normal \\
\hline & & $22-24 / 12$ & Tunisia-central Mediterranean Sea & High \\
\hline & & $25-26 / 12$ & Dissolving & Normal to Null \\
\hline & & $27-28 / 12$ & Tunisia-Mediterranean Sea & Low to normal \\
\hline & & 29/12-2/1 & Tunisia-Mediterranean Sea & Normal to very high \\
\hline & & $3 / 1$ & Dissolving & Normal \\
\hline \multirow[t]{7}{*}{12.} & 1990 & $6-7 / 12$ & South Italy & Normal \\
\hline & & $8 / 12$ & Dissolving eastward & Low \\
\hline & & $9-13 / 12$ & From Germany to North Italy and Tyrrhenian Sea to Ionian Sea & Normal \\
\hline & & $14-16 / 12$ & Enlarging eastward & High to normal \\
\hline & & $17-24 / 12$ & Confuse situation & Low \\
\hline & & $25-28 / 12$ & West Sicily to Calabria and Libya & Very high to high \\
\hline & & $29 / 12$ & Dissolving & Low \\
\hline \multirow[t]{6}{*}{13.} & 2000 & $7 / 9$ & North France & Null \\
\hline & & $8 / 9$ & Sardinia to Calabria & High \\
\hline & & $9 / 9$ & Southern Sicily & High to very high \\
\hline & & $10 / 9$ & Eastern Sicily & Very High \\
\hline & & $11 / 9$ & Aegean Sea & Low \\
\hline & & $12-13 / 9$ & Tyrrhenian Sea & Null \\
\hline
\end{tabular}

is 163 , and the mean number of victims is 42 , which is several times higher than the respective values obtained for the previous groups (5 for events of Type A and 7.5 for Type B).

3.3 Meteorological synoptic patterns preceding analysed DHEs

We analysed the meteorological conditions over the Mediterranean Sea preceding the selected DHEs using data published by the Italian Air Force (Aeronautica Militare, a-b, various years). Data concerning meteorological conditions both on the ground and in the upper air flow systems have been considered using online sources (NOAA).

The analysed DHEs show some similarities in the antecedent conditions (Table 2). All DHEs were observed from September to February, and the only one that occurred in February (No. 4) was very brief. Only one DHE, almost anomalous, was observed in September (No. 13). Two DHEs beginning in December were observed, but only after 1972 . Excluding the latest three DHEs and No. 4, the DHEs begin in October to November due to the dissolution of the Azores high pressure.

During each DHE, the centres of cyclonic area always developed between the western Mediterranean Sea, the Tyrrhenian Sea and north-western Africa, and generally moved slowly, dissolving eastwards or north-eastward. During the DHE, the cyclonic conditions were almost stable for some days (Nos. 1, 2, 4, 9, 10, and 13) or suffered short breaks (Nos. 3, 5, 6, 7, 8, 11, and 12), producing a sequence of a few rainy days separated by periods in which meteorological conditions improved slightly. In the latter case, a transitory slight weakening of cyclonic conditions was observed, as for Nos. 3 and 12; in the remaining cases, a clear break between two different perturbations is recognised.

We stress that, for 10 DHEs (Nos. 1, 2, 5, 6, 7, 8, 9, 10, 11, and 12), the persistent effects of perturbation over Calabria are tied to the antecedent appearance of relevant low-pressure fields in two different areas to the west. The former lowpressure is generally located in north-western Africa, Spain or between these areas, while the latter is located northward, in an area bounded by the western Mediterranean Sea, France, Spain or the northern Atlantic. The former barometric depression ensured the inflow of African masses of warm air, while the latter permitted the inflow of very cold air masses. In this way, near the centre of the Mediterranean, a cold front met a warm one, causing strong and lasting storms. Figure 5 presents an example of DHE No. 11, one of the more widespread events, during which the daily rain of $7 \%$ of available gauges was the maximum value of the 1921-1980 period (Petrucci et al., 1996). In the following, this kind of antecedent conditions has been named the "double effect" in order to discriminate it from the usual precipitation link to the simple movement of Atlantic depressions. 


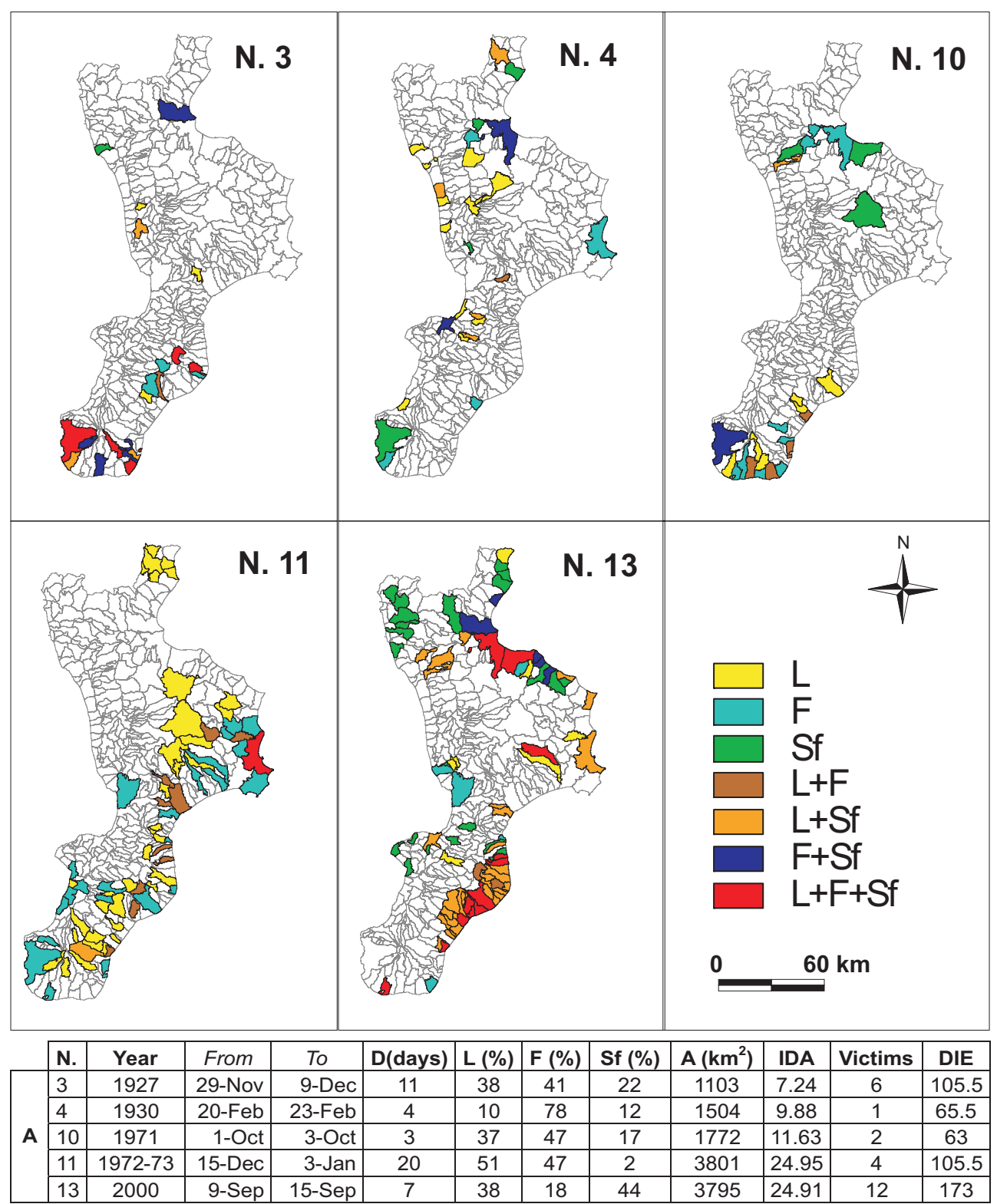

Fig. 2. DHEs of Type A. Each event is shown labelled with its number and municipalities hit coloured according to the type/s of phenomena that occurred there (see legend L=Landslides, $\mathrm{F}=$ floods, $\mathrm{Sf}=\mathrm{Secondary}$ floods). In the table, the main features of the events are described briefly (abbreviation are the same as in Table 1).

\subsection{Analysis of triggering rainfall}

A network of rain gauges characterised by adequate density and a long-lasting daily rainfall series is available for Calabria (Regione Calabria). For return period analysis, the number of available rain gauges ranges from 65 to 218 for the whole set of DHEs. The available time series range from 65 to 81 years for DHEs Nos. 1 to 6, and they last more than 159 years for DHE No. 7 due to modernisation of the rain gauge network that occurred after 1950. This figure could cause an underestimation of $T$ in some areas for the events with lower gauge density.
We assessed the maximum return period $(T)$ of daily rainfall using the approach proposed by Versace et al. (1989). According to these authors, Calabria can be divided into three rainfall sub-zones: the Tyrrhenian, Central and Ionian sub-zones. For each sub-zone, they evaluated the parameters of the TCEV probability distribution function and the bestfitting function of $T=f\left(X^{\prime}\right)$ where $X^{\prime}$ is the growth factor $\left(X^{\prime}\right)(1)$ :

$X^{\prime}=h_{d} / m H$

where $h_{d}$ is the daily rainfall for which $T$ should be assessed 


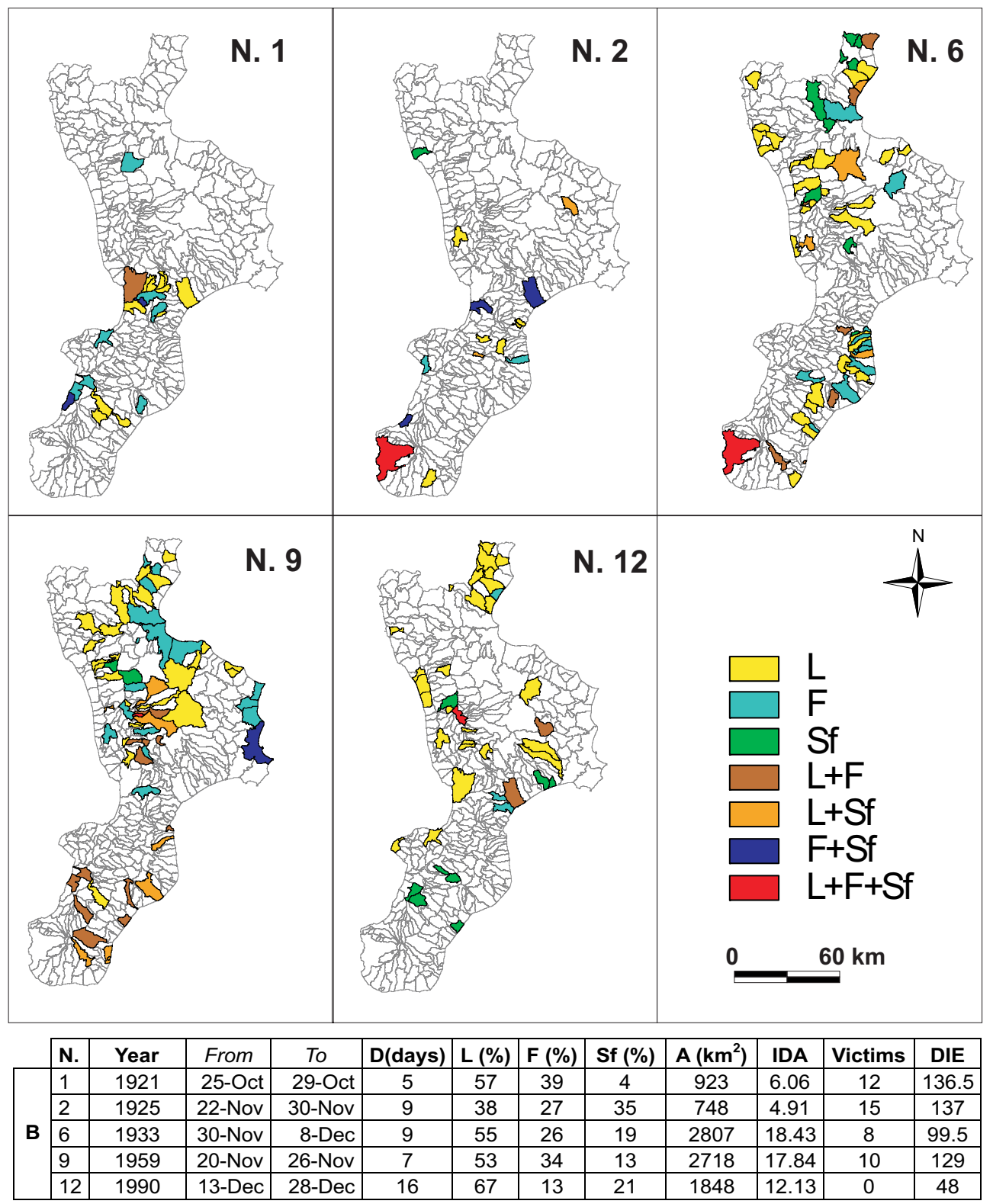

Fig. 3. DHEs of Type B. Each event is shown labelled with its number and municipalities hit coloured according to the type/s of phenomena that occurred there (see legend in Fig. 2). In the table, the main features of the events are described briefly (abbreviation are the same as in Table 1).

and $\mathrm{mH}$ is the average of the annual maxima of daily rainfall observed at the same gauge.

For each gauge and event, using this approach, we assessed the maximum values of $T$ and converted this information into a regional map of $T$ values; the peak $T$ at each gauge in each event was used to plot the max-map (Fig. 6). The succession of barometric conditions and rainfall in each event is briefly described in Table 2 .

Taking into account that the Catanzaro Narrow (Fig. 1) divides the region into two parts from north to south, rainfall of maximum exceptionality class always hits the southern and narrowest portion during the selected events. Some local exceptions, mainly in the southernmost peninsula, were observed in DHEs Nos. 1, 2, 9, and 12. If we consider an ideal axis between the Tyrrhenian and Ionian coasts, the region can be divided into portions again: the eastern side was hit in each DHE by rainfall of any class. The main exceptions are located in the northern sector, where rains of $T$ class 4 were observed only in a narrow area. No rain areas were observed frequently in the north-western sector (DHEs 1, 3, 5, 7, 8, 9, 10,11 , and 13). 


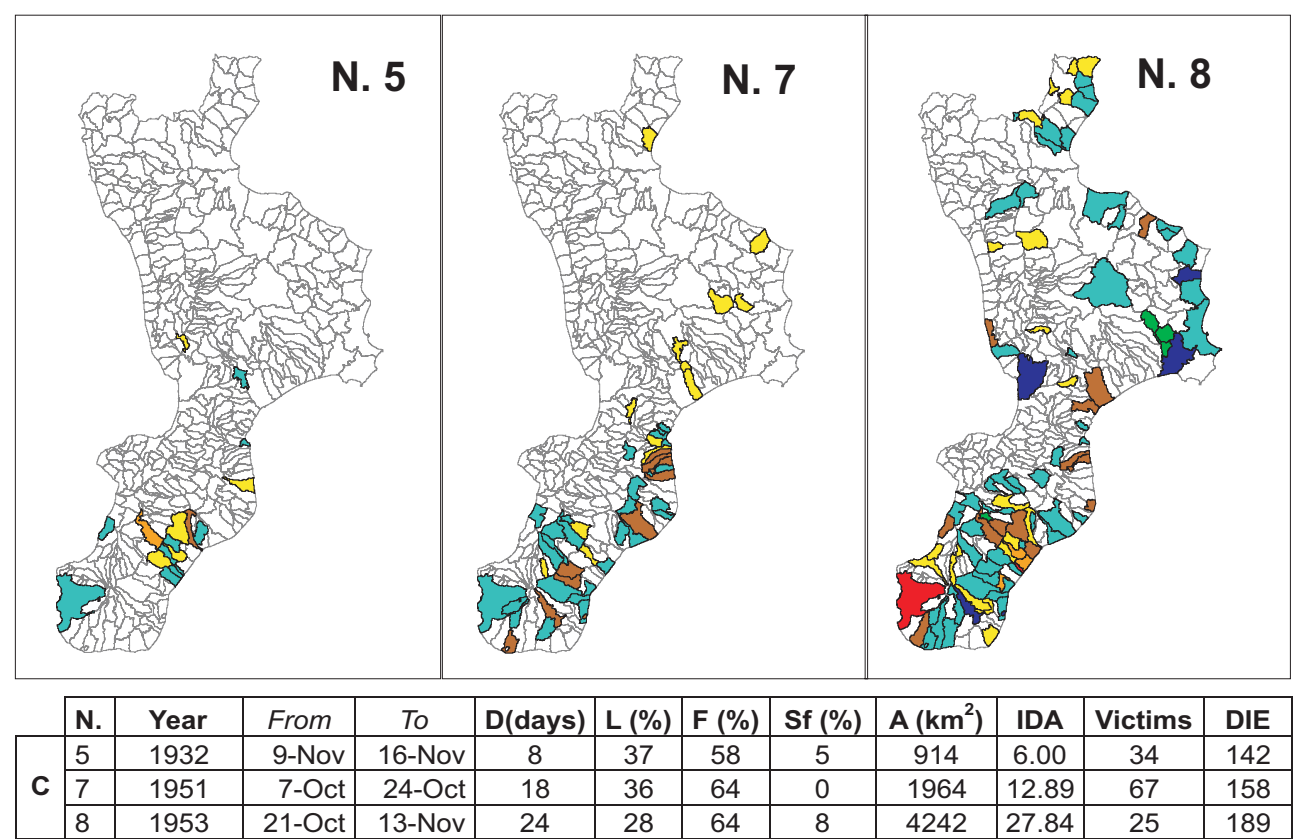

Fig. 4. DHEs of Type C. Each event is shown labelled with its number and municipalities hit coloured according to the type/s of phenomena that occurred there (see legend in Fig. 2). In the table, the main features of the events are described briefly (abbreviation are the same as in Table 1).

Because of the above-mentioned double effect of meteorological antecedent conditions, the most exceptional daily rainfall (in some cases so high as to be considered almost outliers) was observed in many DHEs. The assessed $T$ peak values were greater than 200 years in DHEs Nos. 1, 6, 7, 8,9 , and 11 , in other words in 6 DHEs of 10 in which the double effect was observed ( 5 cases for $T>1000$ years). The exceptions are mainly due to perturbations centred near the boundary of the region. In the case of DHE No. 2, the highest exceptionality of rainfall was observed to the north of Calabria, in the neighbouring Basilicata region (for example, the daily peak value of the available data period 1922-2000 was observed at the Lauria gauge). In the case of DHEs 5 and 10 , this highest exceptionality rainfall happened in the open sea, particularly on the southern Ionian coast. In the case of DHE 12, the rainfall of highest exceptionality fell in both areas, to the north of the region and on open sea.

\section{Data analysis}

Analysing the elaborations of collected data, we can outline some interesting features.

During the study period, we recognise three main types of DHEs

(a) Types of events.DHEs of Type A start in the northernmost sectors of the region, and then move to the S-SE. The season of occurrence is the longest one, from
September to February and, in several cases, floods are the prevailing type of phenomenon. Rainfall fell almost on the whole region; the $T$ value is generally high, but rainfall was extremely exceptional only for DHE No. 11. This is due to the combined effect of a sequence of a few days characterised by high intensity rain and a low spatial incidence of very high $T$ values (particularly in the cases of DHEs Nos. 4, 10 and 13). The mean value of the IDA is $16 \%$, and of the DIE is 102 . The number of victims ranges from 1 and 12 .

During DHEs of Type B, all of the regional sectors involved are hit almost simultaneously and repetitively. The season of occurrence, lasting from the end of October to the end of December, is within that of Type A. These events mainly trigger landslides. This group contains the events that involve the largest regional sectors. In Type B DHEs, neither the double effect nor extreme daily rainfall were observed. In terms of rainfall exceptionality, DHEs Nos. 2 and 12 show secondary relevance. In this case, the average of DIE is the lowest (91), and this group includes the only DHE that did not cause fatalities. In the remaining cases, the number of victims remains under 15 . Some damage caused by event No. 9 , belonging to this group, are shown in Fig. 7. It should be highlighted that the DIE value of any Type B event ranks from fifth- to ninth-highest, again with the exception of event 12 . On a scale of severity, events belonging to Type $\mathrm{C}$ seem to be the most devastating. These events hit the eastern side of the re- 


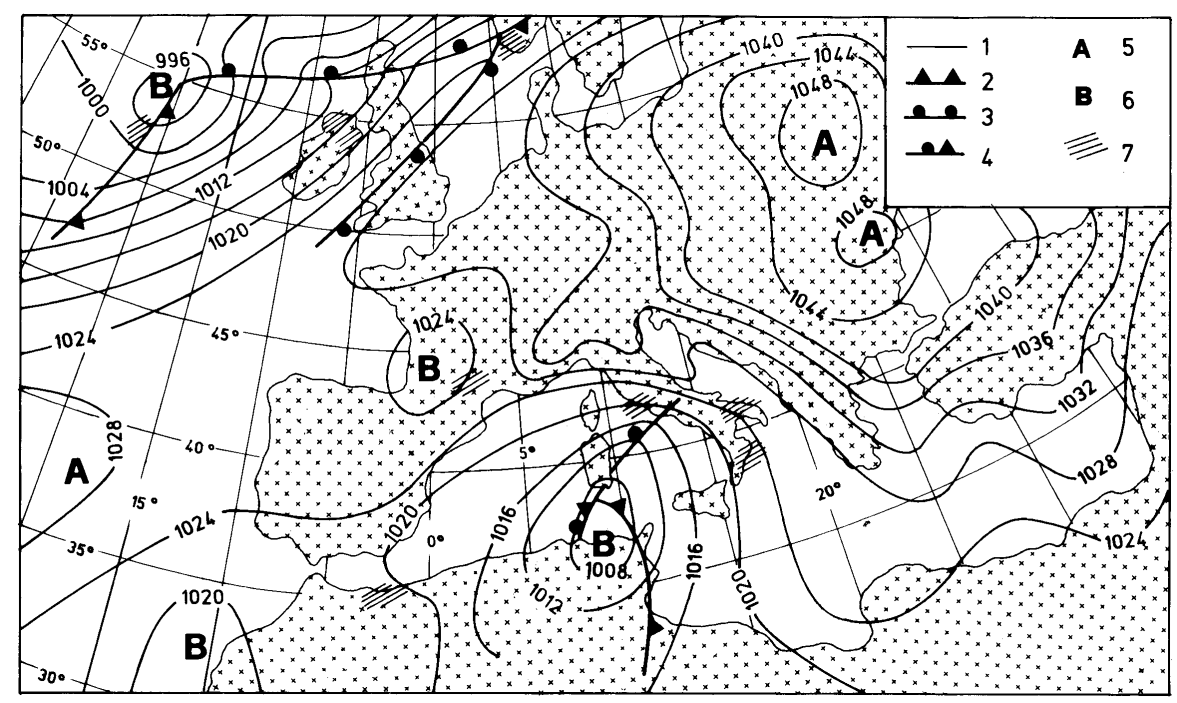

Fig. 5. Meteorological map of 31 December 972 (event No. 11). (1) Barometric line (mm Hg), (2) cold front, (3) warm front, (4) occluded front, (5) local pressure maximum, (6) local pressure minimum, and (7) rain.

gion, mainly the SE sector. Their season of occurrence is limited to October and November, and the prevailing phenomena are floods. In every Type C DHE, both the double effect and extreme daily rainfall were observed, especially for DHEs 7 and 8. The mean value of the IDA is $16 \%$, and of the DIE is 163 , the highest among the three groups of DHEs. The DIE of Type C events ranks from first- to fourth-highest. The mean number of victims is 42 , several times higher than the values obtained for the previous groups (5 for group A and 7.5 for B).

(b) Number of victims. If the number of victims is assumed to be an indicator of the event severity, floods are the most dangerous type of phenomenon in Calabria. The 196 fatalities during the 85-year analysed period (from 1921 to 2005) were caused primarily by floods (77\%) and subordinately by landslides (23\%). Except for one recent event (No. 12), all of the others caused some fatalities, where the mean value of victims for an event is 15 . It must be taken into account that we only analysed the most severe DHEs that occurred in the study period, so less severe events must also be investigated and accounted for to obtain the total number of fatalities caused by DHEs in the analysed period.

(c) Municipalities hit. During the 13 analysed DHEs, 263 municipalities (64\% of all of Calabria's municipalities) were hit by some type of damage. Most of the municipalities have been hit only by one $(28 \%)$, two $(14 \%)$ or three events $(11 \%)$. We classified the municipalities according to the number of DHEs that have affected them (Fig. 8). It can be seen that, during the studied events, the great majority of municipalities of

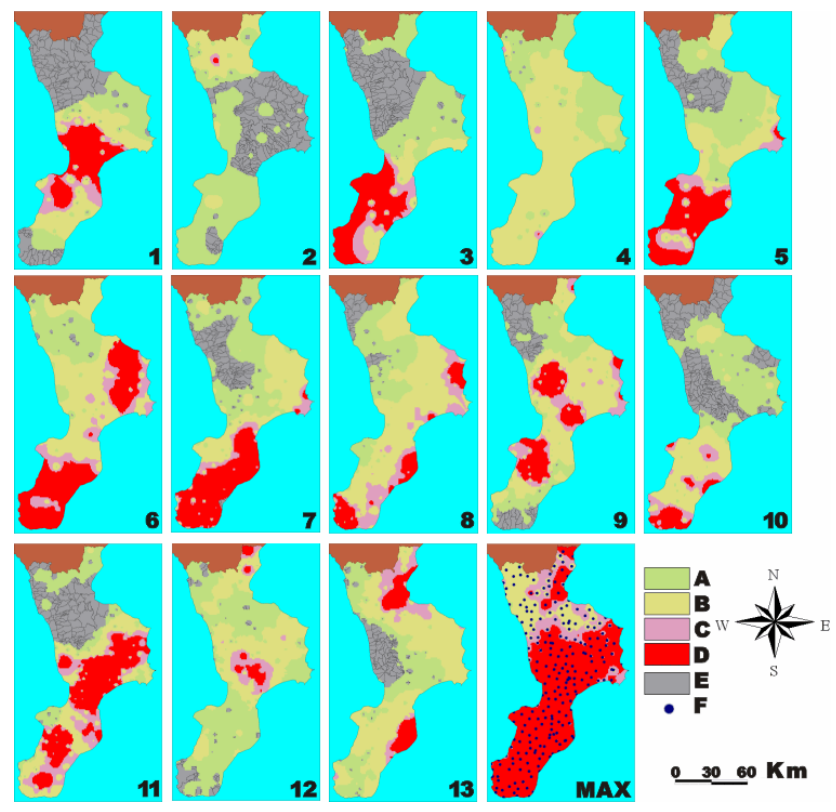

Fig. 6. Return period maps and locations of available rain gauges ( $T$, year). Map 1-13: map of DHE of respective number: Max map: the peak $T$ value of each gauge for each event was used to define the $T$ maximum map. (A) $T<2$, (B) $2<T<10$, (C) $10<T<20$, (D) $T>20$, (E) municipalities (no rain), (F) rain gauge.

the S-SE sector of the region have been hit more than 3 times and some have even been hit more than 5 times. Others municipalities hit several times are located on the eastern side of the region, in both the central and the northern sectors. The municipalities that were affected by only one or two events are located along an irregular area bordering the western side of the region. 

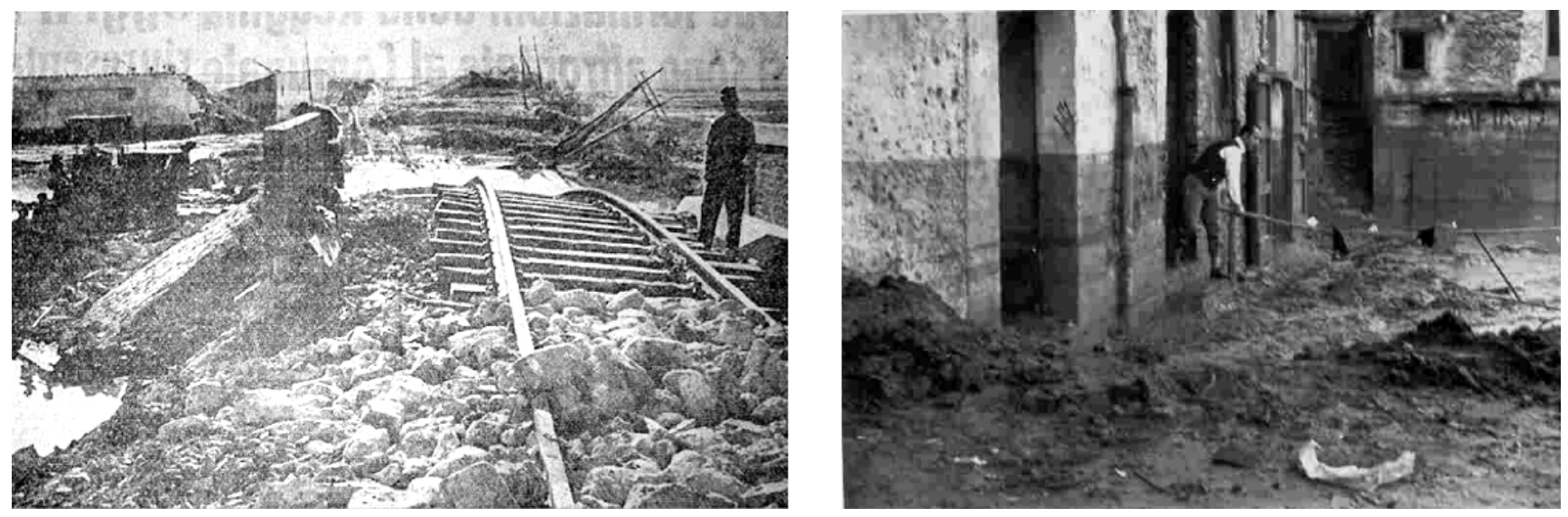

Fig. 7. Some damage caused by event No. 9 (1959). On the left, the regional railways damaged in northern Calabria (photo published in the newspaper: La Gazzetta del Sud). On the right, a disastrous flood in Cosenza town (central Calabria); the photo comes from HistArc.

(d) Duration of DHEs. The events can be defined as short, lasting less than 12 days (Nos. 1, 2, 3, 4, 5, 6, 9, 10, 13), or long, lasting longer than 12 days (Nos. 7, 8, 11,12 ), where $69 \%$ of the analysed DHEs fall into the short group. No clear distinction can be made by cross-checking duration and month during which the events developed. Nevertheless, 3 of the 5 long DHEs started in December (Nos. 8, 11, and 12), and the shortest events occurred at the beginning and end of the period of occurrence (No. 4 in February and No. 10 at the beginning of October). No direct relationships can be observed between the duration of the event and the area hit, also expressed by the IDA. However, it must be taken into account that data concerning the older events could be underestimated, because of documents lost from the archives or, for data extracted from newspapers, a lack of regional headings in the first part of the XXth century. The practical implications of this are that the DHEs are detected, but that their IDAs could be underestimated.

(e) Trend of DHEs. We analysed an 85-year period, during which 13 DHEs occurred, where this represents a mean of 0.15 DHEs/year. This frequency is about $0.22 \mathrm{DHE} / \mathrm{year}$ during the first half of the study period (1921-1962) and decreases to 0.10 DHE/year in the second half (1963-2005). The frequency of the DHEs in the latest decades is therefore lower than in the first part of the past century. In addition, we note that, fortunately, the severe events of Type $\mathrm{C}$ are confined to the first part of the XXth century. There are more than 50 years in which the meteorological conditions leading to this type of event do not occur.

\section{Conclusions}

We analysed an 85-year period during which 13 DHEs occurred. During these events, damaging hydrogeological phenomena, including landslides, floods and secondary floods, caused severe damage all over the Calabria region. We schematised the meteorological conditions preceding the DHEs and linked them to the level of daily rainfall exceptionality. The most relevant rainy phenomena were due to a double effect: the persistent effect of perturbation over Calabria tied to the prior appearance of relevant low-pressure fields in two different areas located to the west.

During the analysed events, $64 \%$ of the municipalities were hit by some type of phenomenon or damage. Most of the municipalities were hit by only one $(28 \%)$ or two $(14 \%)$ events. The durations of the events were extremely variable: $69 \%$ of the cases lasted less than 12 days, and no relationships have been found when cross-checking this parameter with the period of event occurrence.

We have sorted the analysed events into three groups, with the first two (A and B) characterised by similar severity levels but showing different space-temporal damage distributions, and the third C) showing the highest severity level, in terms of both damage and victims.

We note that the frequency of DHEs is roughly decreasing. This frequency is about 0.22 DHEs/year during the first half of the study period (1921-1962) and decreases to 0.10 DHEs/year in the second half (1963-2005). Fortunately, the most severe type of events, namely events of Type $\mathrm{C}$, are confined in the first part of the XXth century. In the last 50 years, the meteorological conditions leading to this type of event have not occurred.

The highest levels of damage, in terms of both the DIE index and victims, were observed during DHEs meteorologically characterised by the double effect. 


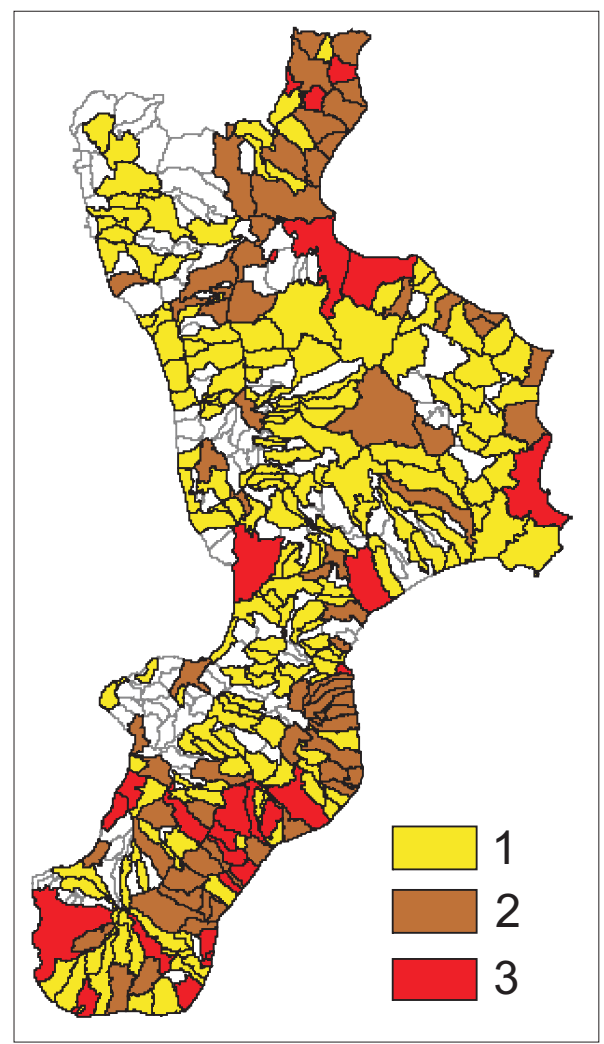

Fig. 8. Classification of municipalities of Calabria according to the number of DHEs that affected them. 1: 1-2 cases; 2: 3-4 cases; 3 : 5 cases or more.

Independent from the type of event, the S-SE and E sectors of the region are the most frequently affected by DHEs, and an irregular area located along the $\mathrm{W}$ side of the region is the less affected by these events (Fig. 7).

Regarding human life, floods are the most dangerous type of phenomenon: the 196 fatalities suffered during the 85-year period were caused primarily by floods $(77 \%)$ and subordinately by landslides $(23 \%)$.

The trend of the number of fatalities is decreasing, probably because of a general improvement in both the locations of settlements and the strength of buildings. No fatalities were caused by one of the most recent events (No. 12). The fatalities caused by the 2000 DHE (No. 13) were due to an underestimation of the risk characterising a flood-prone area in which a campsite was placed. If this risk evaluation had been performed correctly, the number of victims in this case would have been zero, because no fatalities were caused elsewhere during the event.

Edited by: A. Loukas

Reviewed by: two anonymous referees

\section{References}

Aeronautica Militare, a: Bollettino meteorologico quotidiano (formerly Bollettino Meteorologico e Aerologico, Bollettino quotidiano d'informazioni, or Bollettino quotidiano tecnico), Servizio Meteorologico, Roma, Italy, 1927-1988.

Aeronautica Militare, b: Cartello meteorologico, Servizio Meteorologico, Roma, Italy, 1956-1988.

Barnikel, F. and Becht, M.: A historical analysis of hazardous events in the Alps - the case of Hindelang (Bavaria, Germany), Nat. Hazards Earth Syst. Sci., 3, 625-635, 2003, http://www.nat-hazards-earth-syst-sci.net/3/625/2003/.

Barry, R. G. and Chorley, R. J.: Atmosphere, wheather and climate, 8th edition, Routledge Ed., London, 421 pp., 2003.

Benito, G., Lang, M., Barriendos, M., Llasat, M. C., Francés, F., Ouarda, T., Thorndycraft, V. R., Enzel, Y., Bardossy, A., Coeur, D., and Bobée, B.: Use of systematic, palaeoflood and historical data for the improvement of flood risk estimation, Review of Scientific Methods, Nat. Hazards, 31, 623-643, 2004.

Buchroithner, M. F.: Meteorological and earth observation remote sensing data for mass movement preparedness, Adv. Space Res., 29(1), 5-16, 2002.

D'Andrea, E. and Petrucci, O.: Gli eventi alluvionali calabresi di dicembre 2002-gennaio 2003, CNR-GNDCI, 2815, Editoriale Bios, Cosenza, Italy, ISBN 88-77-344-6, 161 pp., 2003.

Devoli, G., Morales, A., and Høeg, K.: Historical landslides in Nicaragua-collection and analysis of data, Landslides, 4, 5-18, 2007.

Diodato, N.: Local models for rainstorm-induced hazard analysis on Mediterranean river-torrential geomorphological systems, Nat. Hazards Earth Syst. Sci., 4, 389-397, 2004, http://www.nat-hazards-earth-syst-sci.net/4/389/2004/.

Giannecchini, R.: Rainfall triggering soil slips in the southern Apuan Alps (Tuscany, Italy), Adv. Geosci., 2, 21-24, 2005, http://www.adv-geosci.net/2/21/2005/.

Glaser, R.: Data and methods of climatological evaluation in historical climatology, Hist. Soc. Res., 21, 56-88, 1996.

Guzzetti, F.: Landslide fatalities and the evaluation of landslide risk in Italy, Eng. Geol., 58, 89-107, 2000.

Highland, L. M.: An account of preliminary landslide damage and losses resulting from the February 28, 2001, Nisqually, Washington, Earthquake, US Geological Survey Open-File report 03-211, online available at: http://pubs.usgs.gov/of/2003/ofr-03-211/, 2003.

Hosking, J. R. M.: The theory of probability-weighted moments, IBM Math., Research Report RC12210, Yorktown Heights, New York, 160 pp., 1986.

Houze, R., Smull, B., and Dodge, P.: Mesoscale organization of springtime rainstorms in Oklahoma, Mon. Weather Rev., 613654, 1990.

I.F.R.C. (International Federation of Red Cross): World disasters report - Focus on recovery, edited by: Walter, J., SADAG, ISBN: 92-9139-075-5, Bellegarde-Valserine, France, 2001.

Ibsen, M. L. and Brunsden, D.: The nature, use and problems of historical archives for the temporal occurrence of landslides, with specific reference to the South coast of Britain, Ventnor, Isle of Wight, Geomorphology, 15, 241-258, 1996.

Jenkinson, A. F.: The frequency distribution of the annual maximum (or minimum) values of meteorological elements, Q. J. Roy. Meteor. Soc., 81, 158-171, 1955. 
Lastoria, B., Simonetti, M. R., Casaioli, M., Mariani, S., and Monacelli, G.: Socio-economic impacts of major floods in Italy from 1951 to 2003, Adv. Geosci., 7, 223-229, 2006, http://www.adv-geosci.net/7/223/2006/.

Llasat, M. C., Barriendos, M., and Barrera, A.: The use of historical data in flood risk assessment. Application to Catalonia (NE Spain) 14th-20th centuries, in: View from the South, Environmental stories from the Mediterranean World, edited by: Armiero, M., CNR, Instituto di Studi sulle Società del Mediterraneo, Napoli, Italy, 95-11, 2006.

Luino, F.: Sequence of instability processes triggered by heavy rainfall in the northern Italy, Geomorphology, 66, 1-4, 13-39, 2005.

Naden, P. S., Calver, A., Reed, D. W., and Reynard, N. S.: Rainfallinduced landslides: a hydrological perspective, Report to CEC, EPOCH, contract 0029, 1993.

NOAA: National climatic data center: http://www.ncdc.noaa.gov/oa/ncdc.html, 2008.

Ogniben, L.: Schema geologico della Calabria in base ai dati odierni, Geologica Romana, 12, 243-585, 1973.

Petrucci, O. and Pasqua, A. A.: The study of past damaging hydrogeological events for damage susceptibility zonation, Nat. Hazards Earth Syst. Sci., 8, 881-892, 2008, http://www.nat-hazards-earth-syst-sci.net/8/881/2008/.

Petrucci, O. and Polemio, M.: Hydro-geologic multiple hazard: a characterisation based on the use of meteorological and geomorphological data, in: Landslides, edited by: Rybar, J., Stemberk, J., and Wagner, P., Balkema Publishers, Lisse, 269-274, 2002.

Petrucci, O. and Polemio, M.: The use of historical data for the characterisation of multiple damaging hydrogeological events, Nat. Hazards Earth Syst. Sci., 3, 17-30, 2003, http://www.nat-hazards-earth-syst-sci.net/3/17/2003/.

Petrucci, O., Chiodo, G., and Caloiero, D.: Eventi alluvionali in Calabria, Rubbettino Arti Grafiche, Soveria Mannelli, Italy, GNDCI 1374, 142 pp., 1996.

Petrucci, O., De Matteis, V., and Versace, P.: Aspetti metodologici nella identificazione dell'impatto al suolo degli eventi alluvionali, Atti del Convegno Nazionale: La Difesa della Montagna, Pub. GNDCI No 2830, 522-530, 2003.

Petrucci, O., Polemio, M., and Pasqua, A. A.: Analysis of damaging hydro-geological events: the case of Calabria region, southern Italy, Environ. Manage., doi:10.1007/s00267-008-9234-z, in press, 2009.
Petrucci, O. and Versace, P.: ASICal: a database of landslides and floods occurred in Calabria (Italy), in: Proc. 1st Italian-Russian Workshop: New Trends in Hydrology, edited by: Gaudio, R., Rende, Italy, 24-26 September 2002, CNR-GNDCI, 2823, 4955, 2004.

Petrucci, O. and Versace, P.: Frane e alluvioni in provincia di Cosenza agli inizi del '900: ricerche storiche nella documentazione del Genio Civile, Editoriale Bios, Cosenza, Italy, ISBN: 88-7740-391-8, 172 pp., 2005.

Petrucci, O. and Versace, P.: Frane e alluvioni in provincia di Cosenza tra il 1930 e il 1950: ricerche storiche nella documentazione del Genio Civile, Nuova Bios, Cosenza, Italy, GNDCI, ISBN: 978-88-6093-029, 2913, 247 pp., 2007.

Polemio, M. and Sdao, F.: The role of rainfall in the landslide hazard: the case of the Avigliano urban area (Southern Apennines, Italy), Eng. Geol., 53(3-4), 297-309, 1999.

Remondo, J., Bonachea, J., and Cendrero, A.: Quantitative landslide risk assessment and mapping on the basis of recent occurrences, Geomorphology, 94, 496-507, 2008.

Regione Calabria: http://www.protezionecivilecalabria.it, 2008.

Rossi, F. and Versace, P.: Criteri e metodi per l'analisi statistica delle piene, Valutazione delle piene, C.N.R.-Progetto Finalizzato Conservazione del Suolo n.165, 63-130, 1982.

Saucier, W. J.: Principles of Meteorological Analysis, Dover Phoenix Edition, 464 pp., 2003.

Sorriso-Valvo, M., Antronico, L., Gaudio, R., Gullà, G., Iovine, G., Merenda, G., Minervino, I., Nicoletti, P. G., Petrucci, O., and Terranova, O.: Carta dei dissesti causati in Calabria meridionale dall'evento meteorologico dell'8-10 settembre 2000, CNRGNDCI, 2859, Geodata n. 45, Rubbettino, Soveria Mannelli, Italy, 2004.

Tortorici, L.: Lineamenti geologico-strutturali dell'Arco CalabroPeloritano, Rendiconti della Società Italiana di Mineralogia e Petrologia, 38, 940-972, 1982.

Versace, P., Ferrari, E., Fiorentino, M., Gabriele, S., and Rossi, F.: Valutazione delle piene in Calabria, CNR-IRPI, Rende, Italy, Geodata No. 30, 157 pp., 1989.

Yang, Y., Lin, H., Guo, Z., and Jiang, J.: A data mining approach for heavy rainfall forecasting based on satellite image sequence analysis, Comput. Geosci., 33(1), 20-30, 2007. 